\title{
Analysis of Issues on the Part of Teachers in College English Intensive Reading Class
}

\author{
Weimin Ji \\ School of Foreign Languages, Northwest University, Xi'an, Shaanxi Province, China, 710127 \\ Email: luckyjwm@163.com
}

\begin{abstract}
This thesis is a case study mainly based on 1) Roger's humanistic psychology with an affective focus and 2) Dell Hymes' concept of Communicative Competence. Through the analysis of the questionnaires designed by the author and the interview afterward, the author has discovered many issues on the part of teachers in College English Intensive Reading class. This paper elaborates and reveals the problems from the quality of teachers, and relationship between teachers and students in the process. Meanwhile, the paper involves some practical solutions accordingly which will be helpful in improving College English Intensive Reading teaching.
\end{abstract}

Index Terms - college English intensive reading class, communicative competence, questionnaire, quality of teachers, relationship between teachers and students

\section{INTRODUCTION}

College English Intensive Reading Course is a comprehensive course that involves learning and teaching of listening, speaking, reading, writing and translating skills within a limited period. They are not simply put together but closely inter-related. During a short class period (usually 50 minutes), teachers have to carry out activities for learners to do various practice in order to meet the demands. Many well-known applied linguists such as H. G. Widdowson claimed that the ultimate aim in language learning is to acquire communicative competence and communicative abilities embrace linguistic skills, which refer to those skills as speaking, hearing, composing and comprehending. (H. G. Widdowson, 1978, p67)

There are many factors accounting for the emphasis on the fostering of college students' communicative competence in English. First, in China there is a great demand for talents who are expert in English. However, most non-English majors show less flexibility in use of English. Besides, the majority of Chinese people who go abroad to pursue their study meet a lot of difficulties. Many people think that these problems are closely related to English teaching in China, which cannot meet the needs of English learners. Actually, there exist many problems in College English Intensive reading class, which has long been considered to be a time-consuming and painstaking task with a little outcome achieved finally; thus, it is always a hot issue discussed among scholars and teachers especially in the field of College English education. Many scholars have carried out their study mainly based on the language teaching theories. This paper aims at revealing some issues on the part of English teachers in the process according to the data the author once collected with questionnaires mainly on what students think about it.

\section{BRIEF INTRODUCTION TO THE QUESTIONNAIRE}

This questionnaire is conducted on what is really going on in College English Intensive Course and especially teachers and learners' attitudes towards it among 550 first-year and second-year non-English majors at Northwest University. 489 respondents handed in valid questionnaires. After that, the author interviewed some of them in order to get specific information about their notions and turned to a dozen College English teachers to get something reproved. It involves students of nearly 30 majors. Thus, the results can represent the learning and teaching of College English Intensive Reading Course especially at Northwest University. The results of this questionnaire have been analyzed with SPSS.

Through the analysis of the questionnaires and the interview afterward, the author has discovered the following serious issues related to teachers that refrain students from achieving optimum learning outcomes in class: 1) Students lack motivation to participate in class activities; 2) Teachers usually dominate the class; 3) The relationship between teachers and students is not satisfactory.

In this paper, only some items related will be used to illustrate the author's idea.

\section{ANALYSIS OF ISSUES ON THE PART OF COLLEGE ENGLISH TEACHERS}

From the past to today, teachers have always been playing a dominating role in College Intensive English class. So far they have been regarded as the source of knowledge and the authority in class. However, what they do and what they are get to be challenged by more and more educators, students and teachers themselves, who become more critical of College English teachers. People assume that teachers are to blame for college students' failing to learn English well. It 
is widely agreed that teachers have to improve their teaching from various aspects.

Brad Anderson once said, "To explain to others you must truly understand. To make others understand as you do, you have to be an exceptional guide." Students in the survey conducted by the author express the similar idea.

Q5 the main problem of the traditional English teaching lies in: A. outdated teaching methods; B. the low professional quality of teachers; C. teachers being less responsible; D. the outdated teaching facility

\begin{tabular}{|c|c|c|c|c|c|}
\hline & & Frequency & Percent & Valid Percent & $\begin{array}{c}\text { Cumulative } \\
\text { Percent }\end{array}$ \\
\hline \multirow[t]{5}{*}{ Valid } & A & 388 & 79.3 & 79.3 & 79.3 \\
\hline & B & 18 & 3.7 & 3.7 & 83.0 \\
\hline & $\mathrm{C}$ & 9 & 1.8 & 1.8 & 84.9 \\
\hline & D & 74 & 15.1 & 15.1 & 100.0 \\
\hline & Total & 489 & 100.0 & 100.0 & \\
\hline
\end{tabular}

Q9 Students' interest is determined by: A. teachers; B. course books; C. students' studying awareness; D. others

\begin{tabular}{|c|c|c|c|c|c|}
\hline & & Frequency & Percent & Valid Percent & $\begin{array}{c}\text { Cumulative } \\
\text { Percent }\end{array}$ \\
\hline \multirow[t]{5}{*}{ Valid } & A & 133 & 27.2 & 27.2 & 27.2 \\
\hline & B & 27 & 5.5 & 5.5 & 32.7 \\
\hline & C & 284 & 58.1 & 58.1 & 90.8 \\
\hline & D & 45 & 9.2 & 9.2 & 100.0 \\
\hline & Total & 489 & 100.0 & 100.0 & \\
\hline
\end{tabular}

According to the tables, only $15.1 \%$ owe it to the outdated teaching facility, all the others think they fail to learn English well because their teachers are not competent enough. Specifically speaking, 79.3\% of the respondents think that the main problem in College Intensive English class is the outdated teaching method and the other 5.5\% claim that teachers' professional quality needs to improved or teachers are not responsible. Besides, 27.2\% of the students believe that teachers determine their interest in English learning. During the interview with the students who choose " $D$ ", the author got to know that "D" also refers to the teaching method. So altogether, a large number of students owe their interest in English learning to their teachers, thus teachers and educators cannot ignore it. In the following part, the author is going to analyze the learning and teaching of College Intensive English Course from two aspects.

\section{A. The Quality of Teachers}

'A good teacher' entails many different definitions. What qualities should a good teacher possess? One of the student teachers in the works of Donald Freeman and Jack C. Richards has discovered the qualities of teachers as "being responsible, keeping their word and striving for achievement" (Donald Freeman and Jack C. Richards, 2002: p152) Coupled with that, it is said, "a good teacher is supposed to be competent not only in their professional knowledge but also in their ability to respect and satisfy different needs of students' cognitive patterns in the teaching process". (Wang Tong, 2001, p340)

As a whole, a good teacher should be defined from two aspects: teachers' professional quality and teachers' ability to organize class activities. People think that it is up to College English teachers to develop students' interest in English, to foster students' learner autonomy, and to create a natural and relaxed learning atmosphere where students can reach their aims. As a result, College English teachers are supposed to improve their learner autonomy first and make them excellent enough to set models for their students. How competent teachers are determines how effectively they teach their students. In class, teachers are expected to conform to the principles of "speaking English as more often as possible and using the mother tongue to a suitable degree", trying to make College Intensive English class communicative. (Tian Shiguo, 2001, p326) Teachers' language competence is one significant factor reflecting teachers' professional quality. In class, language used by teachers has to be as close to life as possible, endowing the interaction between students and teachers with practical meaning. In this way, students can be guided to focus more on conveying meaning during the interactions. Plus, College English teachers should also try to make themselves acquainted with the second and foreign language teaching theories and the theories of second and foreign language acquisition. Being equipped with the knowledge of the regular patterns of foreign language learning, teachers can conduct the effective teaching activity.

Together with it, College English teachers are expected to be capable of organizing various activities, which can motivate students to speak English as possible as they can. The learning outcomes will be optimum if those activities are designed to be closely related to the course materials and meaningful as well. In the process, teachers are better to be easy-going and out-going in order that students feel they are encouraged to consult teachers or turn to teachers for help 
when necessary.

\section{B. Relationship between Teachers and Students in College English Intensive Reading Class}

The relationship between teachers and students are social as well as emotional. The frequent interaction between them is good for them to cultivate mutual trust, understanding and cooperation in class activities. Teachers should be both teachers and friends to students, which will definitely promote students' motivation to study and help them achieve the optimum learning. Nevertheless, it seems not easy for both teachers and students to adopt this idea. Several reasons can account for it.

The basic reason is the one related to the concepts of teachers and students on their respective roles. Traditionally, teachers play the central roles in class while students are seen as "receptacles to be filled with knowledge." According to the traditional "the jugs and mugs" theory, teachers are compared to "a large jug of knowledge which is poured into the learner 'mugs' or receptacles, which in turn can only accept a certain amount of that knowledge according to the size of the learner's IQ." (Marion Williams \& Robert L. Burden, 2000, p58) Although teachers and students know that it is not appropriate to think so, they do not take pains to change the situation because they have long been used to it. Plus, like what has been talked about in the above, Chinese students are not independent enough and they tend to rely on others to set the pace for them. In other words, students like to be followers rather than the leaders in class discussion. Perhaps this is also influenced by Chinese culture---being modest. Thus, when asked about the importance of teachers and students in class, nearly $50 \%$ of the students agree that teachers play a more important role than students do.

Q11 I___ that teachers play a more important role than students do in class. A. can't agree more; B. agree; C. do not agree; D. do not agree completely

\begin{tabular}{|cc|c|c|c|c|}
\hline & & Frequency & Percent & Valid Percent & $\begin{array}{c}\text { Cumulative } \\
\text { Percent }\end{array}$ \\
\hline Valid & A & 24 & 4.9 & 4.9 & 4.9 \\
& B & 214 & 43.8 & 43.8 & 48.7 \\
C & 222 & 45.4 & 45.4 & 94.1 \\
& D & 29 & 5.9 & 5.9 & 100.0 \\
& Total & 489 & 100.0 & 100.0 & \\
\hline
\end{tabular}

There has been existing such a concept that students are not expected to challenge what teachers do or say. What students can do is to show full respect for teachers. They are afraid they cannot get high marks if they do not obey their teachers. In this case, it is up to teachers to encourage students to talk freely by creating a safe environment in class for students.

Moreover, time for both teachers and students to establish a friendly relationship is a problem. It is a fact that teachers and students cannot interact with each other since teachers will leave the classroom immediately after class is over. It is impossible for them to maintain a friendly and equal relationship by talking face to face. Even though they want to communicate, they cannot because teachers usually occupy themselves with many things after class and students have many other subjects to learn. To solve this problem, the internet maybe provides teachers and students with a platform where they can talk to each other without being refrained by time. In addition, everybody likes to make friends with those who favor them. Therefore, it is better for teachers to form the habit of praising or encouraging students instead of looking for faults in them or discouraging them when they make mistakes. As a rule, the negative comments made by teachers on students will severely hurt students' self-esteem and confidence for quiet a long time and even their whole life. Here is an example about the effect of teachers' comments on students. "One student said that she never thought that she was imaginative and had good ideas because she had received many negative comments from the teacher." (Donald Freeman and Jack C. Richards, 2002, p107) According to the cognitive theory, learners typically progress from declarative knowledge (know that) to procedural knowledge (know how). Errors of students result not from lack of declarative knowledge but from procedural knowledge. Therefore, the solution to this problem is to provide conditions of learning that enables students to practice using their knowledge in authentic communicative situations. Apart from that, people who support communicative teaching claim, "Teachers should try to tolerate linguistic mistakes students make in class but not correct them too often lest students' continuous language practice be interrupted". (Tian Shiguo, 2001, p158)

To sum up, both teachers and students are supposed to attempt to change their stereotyped idea. Students should no longer be considered as passive containers for knowledge. Instead, they are learners with high self-esteem. In the teaching process, it is up to teachers not only to impart students with knowledge but also to interact often with students so that students can become independent and enthusiastic about English learning and finally develop their learner autonomy. In terms of fulfilling this change, teachers should take on more responsibility by doing something consciously to realize it.

\section{CONCLUSION}


The teaching and learning of College English Intensive Course is a terribly complicated process in which hosts of things are involved. Anyway, it is widely recognized that there is no any right way to teach. In this thesis, the author just intends to draw the attention of educators and College English teachers to some issues in the teaching and learning process that cannot be ignored in order to turn out the excellent talents who not only do well in their majors but also acquit themselves brilliantly in English. Nevertheless, it should be admitted that the existence of the present situation should be analyzed not only from the aspect of teachers but from the aspect of students, the current Chinese exam system and teaching materials. Anyway, although there are many contradictions in the process, they will be settled if more educators and College English teachers contribute their ideas they get by observing the virtual teaching activities and studying the theories of second and foreign language acquisition and the theories of foreign language teaching.

\section{REFERENCES}

[1] Donald Freeman \& Jack C. Richards. (2002). Teacher Learning in Language Teaching. Shanghai: Shanghai Foreign Language Education Press.

[2] H. G. Widdowson. (1978). Teaching Language as Communication. Shanghai: Shanghai Foreign Language Education Press.

[3] Marion Williams \& Robert L. Burden. (2000). Psychology for Language Teachers. Beijing: Foreign Language Teaching and Research Press.

[4] Tian Shiguo. (2001). English Language Teaching and Practice. Beijing: Higher Educational Press.

[5] Wang Tong. (2001). Respecting Individual Differences in Students' Cognitive System--the Application of Multi-intelligence Theories in English Teaching. The Research Center of Beijing Foreign Languages University. Collection of Academic Essays. Beijing: Foreign Language Teaching and Research Press.

Weimin Ji was born in Xinxiang, China in 1979. She received her M.A. degree in linguistics from Northwest University, China in 2008.

She is currently a lecturer in School of Foreign Languages, Northwest University, China. Her research interests include college English teaching, western culture. 